Article

\title{
Assessing an Integral Treatment for Landfill Leachate Reverse Osmosis Concentrate
}

\author{
Javier Tejera ${ }^{1}$, Daphne Hermosilla ${ }^{2,3, * \mathbb{C}}$, Ruben Miranda ${ }^{1} \mathbb{C}$, Antonio Gascó ${ }^{2}{ }^{\mathbb{C}}$, \\ Víctor Alonso ${ }^{4} \mathbb{D}$, Carlos Negro ${ }^{1}$ and Ángeles Blanco ${ }^{1, * \mathbb{D}}$ \\ 1 Department of Chemical Engineering and Materials, Chemistry Science Faculty, Ciudad Universitaria s/n, \\ Complutense University of Madrid, 28040 Madrid, Spain; jttejo@ucm.es (J.T.); rmiranda@ucm.es (R.M.); \\ cnegro@ucm.es (C.N.) \\ 2 Department of Forest and Environmental Engineering and Management, Universidad Politécnica de Madrid, \\ E.T.S.I. Montes, Forestal y del Medio Natural, C/ José Antonio Novais 10, 28040 Madrid, Spain; \\ antonio.gasco@upm.es \\ 3 Department of Agricultural and Forest Engineering, University of Valladolid, EIFAB, \\ Campus Duques de Soria, 42005 Soria, Spain \\ 4 Department of Applied Physics, University of Valladolid, EIFAB, Campus Duques de Soria, \\ 42005 Soria, Spain; victor.alonso.gomez@uva.es \\ * Correspondence: daphne.hermosilla@upm.es (D.H.); ablanco@ucm.es (Á.B.); \\ Tel.: +34-91-06-71657 (D.H.); +34-91-394-4247 (Á.B.)
}

Received: 26 October 2020; Accepted: 23 November 2020; Published: 28 November 2020

\begin{abstract}
An integral treatment process for landfill leachate reverse osmosis concentrate (LLROC) is herein designed and assessed aiming to reduce organic matter content and conductivity, as well as to increase its biodegradability. The process consists of three steps. The first one is a coagulation/flocculation treatment, which best results were obtained using a dosage of $5 \mathrm{~g} \mathrm{~L}^{-1}$ of ferric chloride at an initial $\mathrm{pH}=6$ (removal of the 76\% chemical oxygen demand (COD), 57\% specific ultraviolet absorption (SUVA), and 92\% color). The second step is a photo-Fenton process, which resulted in an enhanced biodegradability (i.e., the ratio between the biochemical oxygen demand $\left(\mathrm{BOD}_{5}\right)$ and the COD increased from 0.06 to 0.4 ), and an extra $43 \%$ of the COD was removed at the best trialed reaction conditions of $\left[\mathrm{H}_{2} \mathrm{O}_{2}\right] / C O D=1.06, \mathrm{pH}=4$ and $\left[\mathrm{H}_{2} \mathrm{O}_{2}\right] /[\mathrm{Fe}]_{\mathrm{mol}}=45$. An ultra violet-A light emitting diode (UVA-LED) lamp was tested and compared to conventional high-pressure mercury vapor lamps, achieving a $16 \%$ power consumption reduction. Finally, an optimized $30 \mathrm{~g} \mathrm{~L}^{-1}$ lime treatment was implemented, which reduced conductivity by a $43 \%$, and the contents of sulfate, total nitrogen, chloride, and metals by $90 \%$. Overall, the integral treatment of LLROC achieved the removal of $99.9 \%$ color, $90 \% \mathrm{COD}, 90 \%$ sulfate, $90 \%$ nitrogen, $86 \% \mathrm{Al}, 77 \% \mathrm{Zn}, 84 \% \mathrm{Mn}, 99 \% \mathrm{Mg}$, and $98 \% \mathrm{Si}$; and significantly increased biodegradability up to $\mathrm{BOD}_{5} / \mathrm{COD}=0.4$.
\end{abstract}

Keywords: coagulation; landfill leachate; reverse osmosis concentrate; photo-Fenton; LED; lime precipitation

\section{Introduction}

Landfill leachate is an extremely harmful wastewater for the environment because it contains a high amount of organic and inorganic pollutants. Several authors have studied different treatment alternatives to manage this highly contaminant-loaded wastewater, including biological [1], physical [2,3], and chemical processes [4,5]. Nowadays, physical processes using pressure-driven membranes (microfiltration and/or ultrafiltration followed by nanofiltration or reverse osmosis) [6-8] are widely used because of the high quality of the permeate water that is obtained. However, these technologies have the drawback of producing a leachate concentrate containing the retained pollutants [9]. This concentrate 
is usually characterized by low biodegradability, high specific ultraviolet absorbance (SUVA) [10,11], and high concentration of inorganic and bio-recalcitrant organic compounds. Therefore, its treatment by conventional biological processes [12] is not possible, and the concentrate is recirculated back to the landfill in most of the cases $[13,14]$. This reinjection increases the content of persistent organic compounds, salts, nitrogen, and phosphorous in the leachate [15], which then increases membrane fouling and progressively limits the efficiency of the treatment in the medium to the long term [16].

Consequently, the implementation of complementary treatment alternatives for landfill leachate reverse osmosis concentrate (LLROC) is necessary. Some reported treatment possibilities are: Membrane distillation [17], evaporation [18], and different advanced oxidation process (AOPs), such as electro-oxidation [12,19,20], ozonation [21,22], sulfate radical-based AOPs [23,24], and Fenton processes [25-27]. For example, Qi et al. (2015) [17] optimized a vacuum distillation membrane system for LLROC, achieving a $97 \%$ chemical oxygen demand (COD) removal at a vacuum pressure of $0.08 \mathrm{MPa}$ and a temperature of $75^{\circ} \mathrm{C}$ for a flux of $200 \mathrm{~L} \mathrm{~h}^{-1}$. However, membrane distillation requires a large investment, and the system suffers high corrosion levels because of the associated evaporation of corrosive gases through the installation. Similarly, Yang et al. (2018) [18] achieved the complete elimination of organics by a co-bio-evaporation process, mixing LLROC with food waste in the following optimum conditions: 1:1.1 LLROC:food waste ratio, and a flux of $0.035 \mathrm{~m}^{3} \mathrm{~kg}^{-1} \mathrm{~h}^{-1}$. $86 \%$ of the water was evaporated, but severe corrosion troubles in the equipment were predicted.

Although AOPs have been reported to have the potential advantage of increasing the biodegradability of LLROC [28] and different types of wastewater, such as, for example, textile effluents [29], the state of the art shows that the high concentration of organic compounds makes AOPs an expensive technology in terms of the reagents dosages and power consumption. In addition, the biodegradability increase may not be enough [30-33]. For example, in the case of electro-oxidation processes using boron-doped diamond electrodes, $89.6-100 \%$ of the COD was removed, but biodegradability only increased up to $\mathrm{BOD}_{5} / \mathrm{COD}=0.2$, by the application of $50-100 \mathrm{~mA} \mathrm{~cm}^{-2}$ for $6 \mathrm{~h}[12,20]$. Different new materials and Fenton-like processes, including the coupling with other technologies, are being developed at laboratory scale to increase treatment efficiency, and reduce sludge production and treatment cost. For example, Wang et al. (2018) [27] studied FePC amorphous alloys to increase the catalytic efficiency, and Liang et al. (2018) [24] reported the use of $\mathrm{Fe}_{78} \mathrm{Si}_{9} \mathrm{~B}_{13}$ as metallic glass to generate hydroxyl and persulfate radicals when $\mathrm{H}_{2} \mathrm{O}_{2}$, persulfate and monopersulfate were used as oxidants.

In order to reduce the cost of AOP treatments, a coagulation/flocculation pretreatment, which may even be easily applied at industrial scale, has been proposed to reduce COD, color, and UV absorbance at $254 \mathrm{~nm}[4,34,35]$. UV absorbance reduction significantly enhances ultraviolet radiation penetration in the media, and, thus, the efficiency of the photo-oxidation processes. Zhou et al. (2011) [35] reported an increase in the removal of contaminants by combining coagulation with different AOPs applied to treat an urban wastewater with a total organic carbon (TOC) of $18 \mathrm{mg} \mathrm{L}^{-1}$. In this case, $49 \%$ of the TOC was removed by combining ferric chloride coagulation with an UVA $/ \mathrm{H}_{2} \mathrm{O}_{2}$ process; whereas less than $3 \%$ of the TOC was removed when the UVA $/ \mathrm{H}_{2} \mathrm{O}_{2}$ treatment was applied standalone.

The use of UV radiation (photo-Fenton) to recycle the iron catalyst for the Fenton reaction and decarboxylate ferric carboxylates [36,37], might be a good alternative to save iron addition and generate less sludge, provided it is sufficiently cheap [38]. Thus, coupling ferric chloride coagulation/flocculation pretreatment with a photo-Fenton process might be a promising alternative for the treatment of LLROC. In fact, the amount of $\mathrm{Fe}^{3+}$ that remains in the leachate after coagulation might be used as the catalyst of the posterior photo-Fenton process. Complementarily, this treatment may increase the biodegradability of the outflowing effluent from the oxidation process, measured in terms of the ratio of the biochemical oxygen demand to the chemical oxygen demand ( $\left.\mathrm{BOD}_{5} / \mathrm{COD}\right)$ [39]. Therefore, it might finally be biologically treated with success. Amor et al. (2015) [39] reported an 89\% COD removal of a landfill leachate by combining a coagulation pre-treatment with $2 \mathrm{~g} \mathrm{~L}^{-1}$ of ferric chloride at $\mathrm{pH}=5$ with a solar photo-Fenton process, when just a $63 \%$ COD removal was achieved by the standalone 
solar photo-Fenton treatment. However, this treatment increases the conductivity of the leachate caused by the addition of iron and chloride, which would inhibit the activity of microorganisms in a biological reactor. Therefore, in this study, we considered a final lime precipitation step aiming to reduce conductivity by removing inorganics, metal ions, more organics, and ammonia nitrogen by air stripping induced by the increase of the $\mathrm{pH}$, which, as a result, will enable its final biological treatment. Some authors have reported the application of lime in a first step of the treatment, or even before a reverse osmosis process [40]; but the addition of lime produced a considerable $\mathrm{pH}$ increase, which is a disadvantage for the photo-Fenton process because it works better under acidic conditions.

High-pressure immersion mercury vapor lamps have been widely used as the UV irradiation source for the photo-Fenton treatment step, although these lamps have a low energy efficiency, with only $20 \%$ of the consumed energy actually contributing to the emission of photons within the UV range [41], and the greater rest consumed in infrared (IR) irradiation losses. This is why other radiation sources have gained importance lately, such as light-emitting diode (LED) technology [42] or solar radiation with the aid of compound parabolic collectors (CPC) or thin parabolic collectors [43,44]. Silva et al. (2016) [44] compared an artificial UV source of radiation with CPCs, reporting that the use of CPCs was $0.4 € \mathrm{~m}^{-3}$ cheaper than the applied artificial UV source in the photo-Fenton treatment of $100 \mathrm{~m}^{3} \mathrm{day}^{-1}$ of urban landfill leachate, but they required a very large installation area and a great investment.

Based on the state of the art, the efficiency of an integrated treatment for LLROC is herein studied. It consists of three steps (namely, coagulation/flocculation, photo-Fenton, and lime addition) with the aim of accomplishing the following objectives: (1) To maximize the removal of COD, TOC, color, and SUVA by a coagulation pre-treatment; (2) to optimize the photo-Fenton oxidation step to maximize COD removal and enhance biodegradability, and to assess a range of pre-treatment options; and (3) to achieve a sufficient reduction of the conductivity of the oxidized LLROC by lime addition to enable a potential final biological treatment. In addition, the reduction of costs by using LED technology as the source of UV radiation in the Fenton process is assessed.

\section{Results and Discussion}

\subsection{Coagulation Pretreatment, Effect of $\mathrm{pH}$ and Coagulant Dosage}

The $\mathrm{pH}$ played an important role in the coagulation process. At lower $\mathrm{pH}$ values, the efficiency of coagulation in terms of COD removal increased, as it has previously been reported by other authors [34,39]. In particular, it is well-known that the COD of LLROC will be reduced by decreasing the $\mathrm{pH}$ in the medium [45] due to the precipitation of humic acids [41,46]. Unfortunately, the high alkalinity of the sampled LLROC $\left(44,125 \mathrm{mg} \mathrm{L}^{-1} \mathrm{CaCO}_{3}\right.$, Table 1$)$ required the addition of a relatively large quantity of sulfuric acid, namely: 16,23 , and $24.5 \mathrm{~g} \mathrm{~L}^{-1}$ of $\mathrm{H}_{2} \mathrm{SO}_{4}$, to reduce the $\mathrm{pH}$ from its initial value of 8.13 (Table 1) to 7.0, 6.0, and 5.0, respectively, before performing the coagulation treatment. The amount of sulfate in the solution consequently increased as the $\mathrm{pH}$ was lowered, rising from an initial value of $2.4 \mathrm{~g} \mathrm{~L}^{-1}$ (Table 1) to $15 \mathrm{~g} \mathrm{~L}^{-1}$ at $\mathrm{pH}=7 ; 25 \mathrm{~g} \mathrm{~L}^{-1}$ at $\mathrm{pH}=6$; and $28 \mathrm{~g} \mathrm{~L}^{-1}$ at $\mathrm{pH}=5$, respectively.

Conductivity also increased, as expected, as the $\mathrm{pH}$ value of the solution was set lower to increase coagulation efficiency, increasing from an initial value of $87.3 \mathrm{mS} \mathrm{cm}^{-1}$ (Table 1) to $90.3,94.4$, and $95.0 \mathrm{mS} \mathrm{cm}^{-1}$ when the $\mathrm{pH}$ was adjusted to $7.0,6.0$, and 5.0, respectively. This may negatively affect the efficiency of the posterior photo-Fenton treatment that is designed to be applied [47], as well as the potential biological treatment that might be performed to the oxidized LLROC afterwards.

Coagulation with ferric chloride achieved COD removals of $43 \%$ at the natural $\mathrm{pH}$ value of the LLROC (8.13; Table 1); $78 \%$ at $\mathrm{pH}=7.0 ; 76 \%$ at $\mathrm{pH}=6.0$; and $71 \%$ at $\mathrm{pH}=5.0$; respectively (Figure 1 ). In addition, whereas a $30 \mathrm{~g} \mathrm{~L}^{-1}$ dose of $\mathrm{FeCl}_{3}$ were required to optimize coagulation at $\mathrm{pH}$ values at or above 7.0, only $5 \mathrm{~g} \mathrm{~L}^{-1}$ was required at the acidic $\mathrm{pH}$ values (i.e., 5.0 and 6.0) because the optimum $\mathrm{pH}$ for coagulation with $\mathrm{FeCl}_{3}$ is about 4-5 [41], and the addition of $\mathrm{FeCl}_{3}$ produces a significant reduction of $\mathrm{pH}$ with the subsequent precipitation of humic acids. In short, decreasing the initial $\mathrm{pH}$ value of LLROC to acid values not only favored a higher coagulation efficiency, but it also significantly reduced 
the optimum coagulant dose to one-sixth of that required at neutral and basic $\mathrm{pH}$ values, which results in a significantly lower treatment cost and reduces chloride content.

Table 1. Initial characteristics of the landfill leachate reverse osmosis concentrate (LLROC).

\begin{tabular}{|c|c|c|c|}
\hline $\begin{array}{l}\text { Parameter } \\
\text { (LLROC) }\end{array}$ & Value $^{2}$ & $\begin{array}{c}\text { Parameter } \\
\text { (Dissolved Fraction) }\end{array}$ & Value $^{2}$ \\
\hline $\mathrm{pH}$ & $8.13 \pm 0.10$ & Chloride, $\mathrm{mg} \mathrm{L}^{-1}$ & $8968 \pm 897$ \\
\hline Conductivity, $\mathrm{mS} \mathrm{cm}^{-1}$ & $87.30 \pm 0.90$ & Sulfate, $\mathrm{mg} \mathrm{L}^{-1}$ & $2431 \pm 243$ \\
\hline $\mathrm{UV}-254, \mathrm{~cm}^{-1}$ & $150 \pm 10$ & Aluminum, $\mathrm{mg} \mathrm{L}^{-1}$ & $4.20 \pm 0.60$ \\
\hline Color, mg Pt L ${ }^{-1}$ & $28,100 \pm 900$ & Iron, $\mathrm{mg} \mathrm{L}^{-1}$ & $2.30 \pm 0.30$ \\
\hline $\mathrm{COD}, \mathrm{mg} \mathrm{O}_{2} \mathrm{~L}^{-1}$ & $21,220 \pm 750$ & Chromium, mg L ${ }^{-1}$ & $1.00 \pm 0.20$ \\
\hline $\mathrm{BOD}_{5}, \mathrm{mg} \mathrm{O}_{2} \mathrm{~L}^{-1}$ & $1273 \pm 100$ & Sodium, $\mathrm{mg} \mathrm{L}^{-1}$ & $6769 \pm 677$ \\
\hline $\mathrm{BOD}_{5} / \mathrm{COD}$ & $0.06 \pm 0.01$ & Potassium, $\mathrm{mg} \mathrm{L}^{-1}$ & $3157 \pm 316$ \\
\hline TOC, mg C L $\mathrm{L}^{-1}$ & $9980 \pm 150$ & Magnesium, mg L ${ }^{-1}$ & $245 \pm 25$ \\
\hline $\mathrm{TS}, \mathrm{mg} \mathrm{L}^{-1}$ & $51,270 \pm 1620$ & Calcium, mg L ${ }^{-1}$ & $19 \pm 2$ \\
\hline $\mathrm{TSS}, \mathrm{mg} \mathrm{L}^{-1}$ & $360 \pm 32$ & Silicon, $\mathrm{mg} \mathrm{L}^{-1}$ & $29 \pm 3$ \\
\hline TDS, $\mathrm{mg} \mathrm{L}^{-1}$ & $50,910 \pm 1230$ & Zinc, $\mathrm{mg} \mathrm{L}^{-1}$ & $0.60 \pm 0.09$ \\
\hline Alkalinity, $\mathrm{mg} \mathrm{CaCO}_{3} \mathrm{~L}^{-1}$ & $44,125 \pm 1023$ & Nickel, mg L ${ }^{-1}$ & $0.38 \pm 0.06$ \\
\hline $\mathrm{TN}_{\mathrm{b}}, \mathrm{mg} \mathrm{N} \mathrm{L}^{-1}$ & $3000 \pm 150$ & Strontium, $\mathrm{mg} \mathrm{L}^{-1}$ & $1.50 \pm 0.30$ \\
\hline
\end{tabular}

${ }_{1}^{1}$ COD (chemical oxygen demand); BOD $_{5}$ (biochemical oxygen demand); TOC (total organic carbon); TS (total solid); TSS (total suspended solid); TDS (total dissolved solid); $\mathrm{TN}_{\mathrm{b}}$ (total nitrogen bonded). ${ }^{2}$ Values are $\mathrm{m} \pm \mathrm{sd}$.

Aluminum sulfate (alum) achieved lower maximum COD removal efficiencies than $\mathrm{FeCl}_{3}$, that is: $25 \%$ at $\mathrm{pH}=8.13 ; 30 \%$ at $\mathrm{pH}=7.0 ; 60 \%$ at $\mathrm{pH}=6.0$; and $43 \%$ at $\mathrm{pH}=5.0$ (Figure 1 ). Optimal $\mathrm{Al}_{2}\left(\mathrm{SO}_{4}\right)_{3}$ dosages were also six times higher $\left(30 \mathrm{~g} \mathrm{~L}^{-1}\right)$ at neutral to basic $\mathrm{pH}$ values than at acidic initial process conditions $\left(5 \mathrm{~g} \mathrm{~L}^{-1}\right)$, as it was the case with $\mathrm{FeCl}_{3}$. Therefore, acidic initial conditions also result in a lower treatment cost to coagulate LLROC more efficiently, but the drawback in this case is the increased sulfate content.

The application of $\mathrm{Al}_{2}\left(\mathrm{SO}_{4}\right)_{3} \cdot 18 \mathrm{H}_{2} \mathrm{O}$ or $\mathrm{FeCl}_{3}$ under acidic conditions achieved worse COD removal treatment efficiency results at $\mathrm{pH}=5$ than at $\mathrm{pH}=6(17 \%$ lower $\mathrm{COD}$ removal in the case of alum, and only $5 \%$ in the case of $\mathrm{FeCl}_{3} ;$ Figure 1 ). This effect is explained by the fact that ferric chloride has better efficiencies in COD removal at $\mathrm{pH}$ values around 4 [45], and at $\mathrm{pH}=6$ and 5 , with a dose of $5 \mathrm{~g} \mathrm{~L}^{-1}$, the final $\mathrm{pH}$ values after coagulation were 4.07 and 3.30, respectively. The lower final $\mathrm{pH}$ at initial $\mathrm{pH}=5$ reduced the efficiency of ferric chloride coagulation. In the case of alum, the optimal $\mathrm{pH}$ for the coagulation process is around 5.5 [48], and the coagulation with $5 \mathrm{~g} \mathrm{~L}^{-1}$ ended in a final $\mathrm{pH}$ of 4.15 and 4.99 , for initial $\mathrm{pH}$ values of 5 and 6, respectively. So, at an initial $\mathrm{pH}$ of 5 and a dose of $5 \mathrm{~g} \mathrm{~L}^{-1}$, the final $\mathrm{pH}$ is far from the optimal for alum coagulation than at initial $\mathrm{pH}=6$.

In general, the best LLROC coagulation results were achieved at a coagulant dose of $5 \mathrm{~g} \mathrm{~L}^{-1}$ at $\mathrm{pH}=6.0$ for both coagulants, but ferric chloride coagulation gave significantly $\left(p<0.001^{* * *}\right)$ better removal of COD, TOC, UV-254, SUVA, and color (Table 2). The differences in COD removal $(60 \%$ and $76 \%$ with alum and ferric chloride, respectively) and in TOC removal (65\% with alum and $75 \%$ with ferric chloride, respectively) are important in order to reduce the cost of reagents in a posterior photo-Fenton treatment. These differences are directly related to the final $\mathrm{pH}$ value reached after coagulation, that is: $\mathrm{pH}=4.99$ for alum and $\mathrm{pH}=4.07$ for ferric chloride, since precipitation of humic acids is produced under $\mathrm{pH}=5$ [45]. 

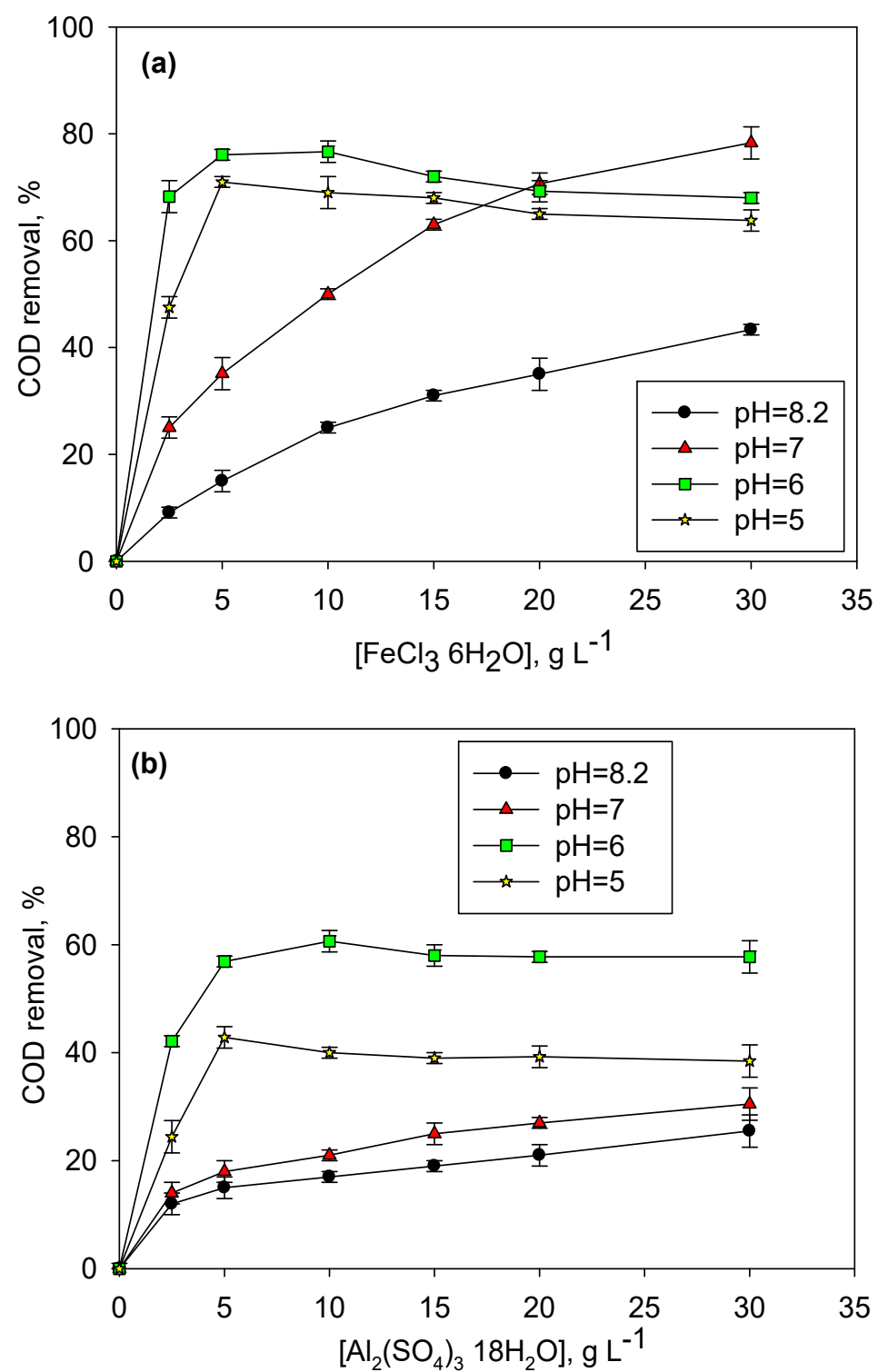

Figure 1. Coagulation of LLROC at different $\mathrm{pH}$ values and coagulant dosage: (a) Ferric chloride, and (b) alum (values are $\mathrm{m} \pm \mathrm{sd}$ ).

Table 2. Characteristics of the LLROC after an optimum coagulation treatment with different coagulants $\left(\mathrm{Al}_{2}\left(\mathrm{SO}_{4}\right)_{3} \cdot 18 \mathrm{H}_{2} \mathrm{O}\right.$ or $\mathrm{FeCl}_{3} \cdot 6 \mathrm{H}_{2} \mathrm{O} ; \mathrm{pH}=6.0$ and dosage of $5 \mathrm{~g} \mathrm{~L}^{-1}$ in both cases).

\begin{tabular}{|c|c|c|c|}
\hline Parameters ${ }^{1}$ & LLROC $^{2}$ & $\mathrm{Al}_{2}\left(\mathrm{SO}_{4}\right)_{3} \cdot 18 \mathrm{H}_{2} \mathrm{O}^{2}$ & $\mathrm{FeCl}_{3} \cdot 6 \mathrm{H}_{2} \mathrm{O}^{2}$ \\
\hline $\mathrm{H}_{2} \mathrm{SO}_{4}, \mathrm{~g} \mathrm{~L}^{-1}$ & - & 25 & 25 \\
\hline Initial coagulation $\mathrm{pH}$ & $8.13 \pm 0.10$ & $6.00 \pm 0.10$ & $6.00 \pm 0.10$ \\
\hline Final $\mathrm{pH}$ & $8.13 \pm 0.10$ & $4.99 \pm 0.10$ & $4.07 \pm 0.10$ \\
\hline Conductivity, $\mathrm{mS} \mathrm{cm}-1$ & $87.30 \pm 0.90$ & $90.20 \pm 0.90$ & $92.30 \pm 0.90$ \\
\hline $\mathrm{COD}, \mathrm{mg} \mathrm{O}_{2} \mathrm{~L}^{-1}$ & $21,220 \pm 1000$ & $8488 \pm 700(60 \%)^{1}$ & $5092 \pm 500(76 \%)$ \\
\hline TOC, $\mathrm{mg} \mathrm{C} \mathrm{L}^{-1}$ & $9980 \pm 100$ & $3493 \pm 100(65 \%)$ & $2495 \pm 100(75 \%)$ \\
\hline $\mathrm{UV}-254, \mathrm{~cm}^{-1}$ & $150 \pm 10$ & $49 \pm 1(67 \%)$ & $16 \pm 1(89 \%)$ \\
\hline SUVA, $\mathrm{L} \mathrm{mg}^{-1} \mathrm{~m}^{-1}$ & $1.50 \pm 0.50$ & $1.40 \pm 0.50(7 \%)$ & $0.64 \pm 0.50(57 \%)$ \\
\hline Color, mg Pt L ${ }^{-1}$ & $28,100 \pm 1000$ & $7700 \pm 400(73 \%)$ & $2160 \pm 200(92 \%)$ \\
\hline $\mathrm{BOD}_{5} / \mathrm{COD}$ & $0.06 \pm 0.01$ & $0.06 \pm 0.01$ & $0.06 \pm 0.01$ \\
\hline
\end{tabular}

${ }^{1}$ SUVA $=100 \cdot$ UV-254/TOC. ${ }^{2}$ Values are mean $(\mathrm{m}) \pm$ standard deviation $(\mathrm{sd})$. Removal results are in brackets. 
The efficiency of a posterior photo-Fenton treatment may be highly affected by the presence of color and $254 \mathrm{~nm}$ UV quenching substances, which are scavengers of this advanced oxidation reaction $[10,11]$. In fact, the efficiency of the photo-Fenton process is highly related to the penetration of $\mathrm{UV}$ radiation into the reaction media, achieving better COD removal at a lower cost in terms of energy consumed (lower reaction time thanks to a greater radiation efficiency) and $\mathrm{H}_{2} \mathrm{O}_{2}$ dosage [10,11] In regard to these issues, ferric chloride achieved better color removal results than alum $(92 \%$ vs. $73 \%$ at its best), resulting in 2160 and $7700 \mathrm{mg} \mathrm{Pt} \mathrm{L}^{-1}$, respectively (Table 2). In addition, UV-254 removal was also higher when ferric chloride was used as the coagulant agent ( $89 \%$ vs. $67 \%$ using alum), resulting in a final value of $16 \mathrm{~cm}^{-1}$ (Table 2). Additionally, whereas SUVA was almost not altered after coagulation with alum (only a $7 \%$ removal), it was reduced by a $57 \%$ after $\mathrm{FeCl}_{3}$ coagulation.

These results are in agreement with Chen et al. (2019) [49] who achieved optimal COD removal values of $30 \%, 61 \%, 75 \%$, and $79 \%$ after coagulating LLROC with alum, PAC, PFS, and ferrous sulfate, respectively. UV-254 removal was reported ranging from $52 \%$ to $85 \%$ following the same positive correlation with COD removal results, as it has been addressed in the present study using ferric chloride and alum. Differences among the results reported by Chen et al. (2019) [49] can be attributed to different wastewater characteristics.

As expected, there were no changes in the $\mathrm{BOD}_{5} / \mathrm{COD}$ ratio $(\approx 0.06$; Table 2$)$ after the essayed coagulation treatments [4]. Considering the photo-Fenton process as the next treatment step in order to enhance biodegradability, we chose to investigate $\mathrm{FeCl}_{3}$-coagulated LLROC. Firstly, this option gave the best coagulation results. Secondly, the residual iron should serve as the catalyst for this advanced oxidation process, thus avoiding the addition of iron from other external sources.

\subsection{Photo-Fenton Treatment}

The optimization of the conventional $100 \mathrm{~W}$ immersion mercury lamp photo-Fenton reaction was therefore just carried out for the two best essayed coagulation pre-treatments, namely those performed at $\mathrm{pH}=6$ using 5 and $10 \mathrm{~g} \mathrm{~L}^{-1}$ of ferric chloride. In both cases, the initial COD before the photo-Fenton treatment was $5000 \pm 100 \mathrm{mg} \mathrm{L}^{-1}$. The main differences between these cases were the initial $\mathrm{pH}$ of the oxidation step ( $\mathrm{pH}=4.07$ and 2.75 for 5 and $10 \mathrm{~g} \mathrm{~L}^{-1}$ of coagulant, respectively) and the remaining dissolved iron content in the media after the coagulation pre-treatment (168 and $800 \mathrm{mg} \mathrm{L}^{-1}$ for 5 and $10 \mathrm{~g} \mathrm{~L}^{-1}$ of $\mathrm{FeCl}_{3} \cdot 6 \mathrm{H}_{2} \mathrm{O}$, respectively). It is well known from the literature that the best conditions to perform a Fenton treatment are $\mathrm{pH} \approx 2.8$ and low $\mathrm{H}_{2} \mathrm{O}_{2} / \mathrm{Fe}$ concentration ratio $\left(\mathrm{H}_{2} \mathrm{O}_{2} / \mathrm{Fe}=20\right)$, which implies adding a high iron content [50]. Nevertheless, an initial pH below 5.0 was considered possibly sufficient to obtain reasonable efficiency due to the production of organic acids through the Fenton reaction itself, which would decrease the $\mathrm{pH}$ to values close to the optimum [51].

The photo-Fenton treatment of previously coagulated LLROC with $5 \mathrm{~g} \mathrm{~L}^{-1}$ of $\mathrm{FeCl}_{3} \cdot 6 \mathrm{H}_{2} \mathrm{O}$ achieved a $40 \%$ reduction of the COD under the best tested reaction conditions $\left(\left[\mathrm{H}_{2} \mathrm{O}_{2}\right] /[\mathrm{COD}]=\right.$ both 2.125 and 1.063; Figure 2a); whereas it resulted in $43 \%$ and $49 \%$ COD reductions at $\left[\mathrm{H}_{2} \mathrm{O}_{2}\right] /[\mathrm{COD}]=2.125$ and 1.063, respectively, after the coagulation pre-treatment with $10 \mathrm{~g} \mathrm{~L}^{-1}$ of $\mathrm{FeCl}_{3} \cdot 6 \mathrm{H}_{2} \mathrm{O}$ (Figure $2 \mathrm{~b}$ ). The higher efficiency achieved at higher $\mathrm{FeCl}_{3}$ dose may be explained by the different initial $\mathrm{pH}$ value (4.07 and 2.75 for 5 and $10 \mathrm{~g} \mathrm{~L}^{-1}$ of $\mathrm{FeCl}_{3} \cdot 6 \mathrm{H}_{2} \mathrm{O}$, respectively) and different dissolved iron concentrations present in the media at the beginning of the oxidation process $\left(168\right.$ and $800 \mathrm{mg} \mathrm{L}^{-1}$ for 5 and $10 \mathrm{~g} \mathrm{~L}^{-1}$ of $\mathrm{FeCl}_{3} \cdot 6 \mathrm{H}_{2} \mathrm{O}$, respectively). 

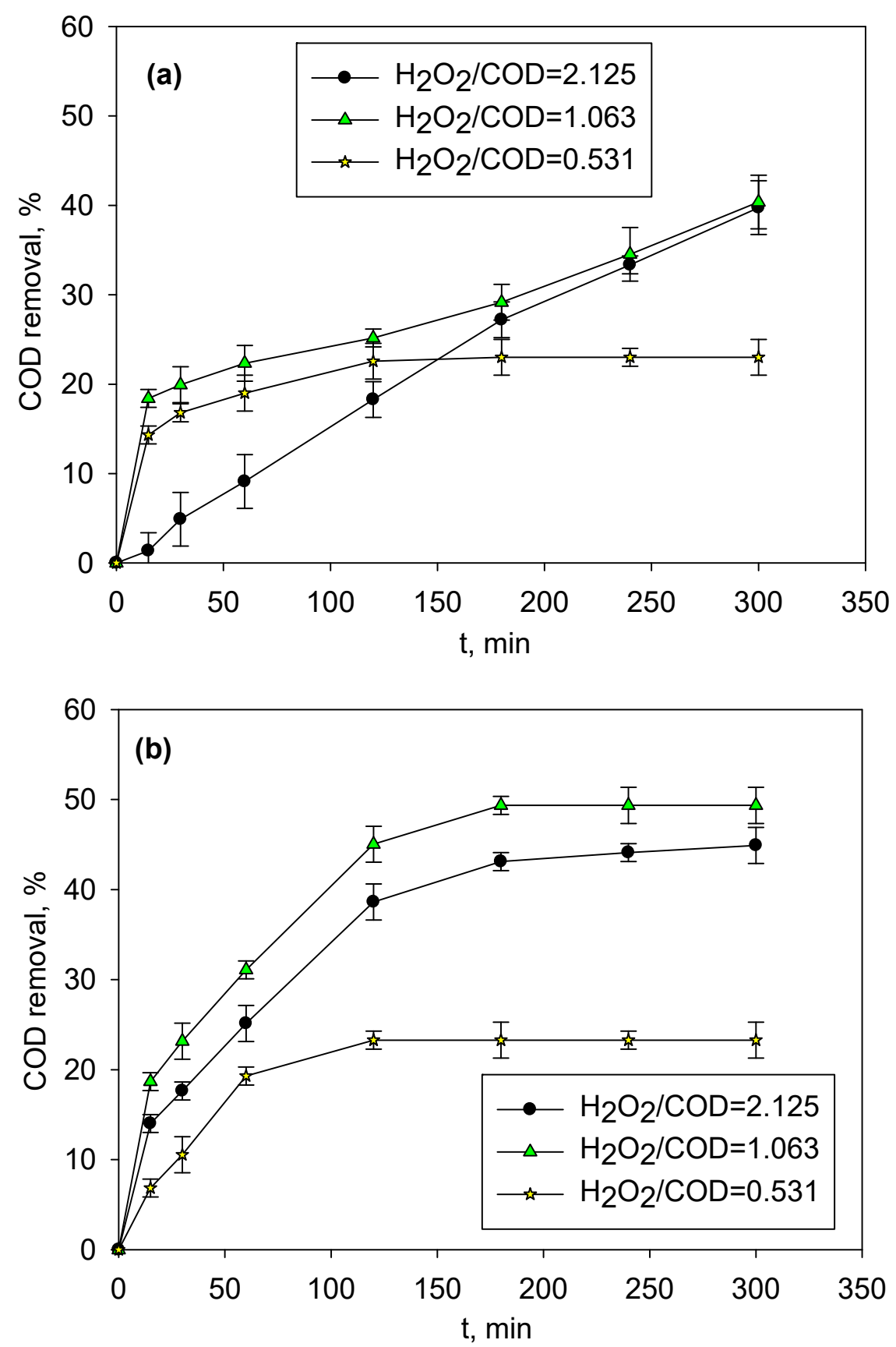

Figure 2. Chemical oxygen demand (COD) removal results of the photo-Fenton treatment of LLROC previously coagulated with ferric chloride using a $100 \mathrm{~W}$ UV mercury lamp. Coagulant dose: (a) $5 \mathrm{~g} \mathrm{~L}^{-1}$ and (b) $10 \mathrm{~g} \mathrm{~L}^{-1}$ (values are $\mathrm{m} \pm \mathrm{sd}$ ).

The reported optimum $\mathrm{pH}$ to perform the Fenton process is about 2.8 [52], and the presence of more dissolved iron after the $10 \mathrm{~g} \mathrm{~L}^{-1}$ coagulation process may have sped up the process. In addition, the reaction time that was required to finish the oxidation process at an $\left[\mathrm{H}_{2} \mathrm{O}_{2}\right] /[\mathrm{COD}]$ ratio of 1.063 (i.e., zero peroxide content in the media) was $5 \mathrm{~h}$ for LLROC pre-coagulated with $5 \mathrm{~g} \mathrm{~L}^{-1}$ of FeCl $\cdot 6 \mathrm{H}_{2} \mathrm{O}$, and $3 \mathrm{~h}$ for the $10 \mathrm{~g} \mathrm{~L}^{-1}$ dose. This is explained by the different $\left[\mathrm{H}_{2} \mathrm{O}_{2}\right] /[\mathrm{Fe}]$ ratio that results in different conditions. For $5 \mathrm{~g} \mathrm{~L}^{-1}$ of ferric chloride pre-coagulation: $\left[\mathrm{H}_{2} \mathrm{O}_{2}\right] /[\mathrm{Fe}]$ ratios of 90,45 , and 23 were achieved for $\left[\mathrm{H}_{2} \mathrm{O}_{2}\right] /[\mathrm{COD}]$ of $2.125,1.063$, and 0.531 , respectively; and for $10 \mathrm{~g} \mathrm{~L}^{-1}$ ferric chloride pre-coagulation: $\left[\mathrm{H}_{2} \mathrm{O}_{2}\right] /[\mathrm{Fe}]$ of 19,10 , and 5 were obtained for $\left[\mathrm{H}_{2} \mathrm{O}_{2}\right] /[\mathrm{COD}]$ of $2.125,1.063$, and 0.531 , respectively. 
The resulting reduction of SUVA indicates that high molecular weight substances have been degraded to smaller ones [53]. SUVA values of $0.18,0.21$, and $0.33 \mathrm{~L} \mathrm{mg}^{-1} \mathrm{~m}^{-1}$ were obtained for $\left[\mathrm{H}_{2} \mathrm{O}_{2}\right] / C O D=2.125,1.063$, and 0.531 , respectively, from a previous initial value of $0.64 \mathrm{~L} \mathrm{mg}^{-1} \mathrm{~m}^{-1}$, in the photo-Fenton treatment of pre-coagulated LLROC with $5 \mathrm{~g} \mathrm{~L}^{-1}$ of $\mathrm{FeCl}_{3} \cdot 6 \mathrm{H}_{2} \mathrm{O}$ (Figure 3a). On the other hand, the photo-Fenton treatment of LLROC pre-coagulated with $10 \mathrm{~g} \mathrm{~L}^{-1}$ of $\mathrm{FeCl}_{3} \cdot 6 \mathrm{H}_{2} \mathrm{O}$ achieved SUVA values of $0.43,0.47$, and $0.51 \mathrm{~L} \mathrm{mg}^{-1} \mathrm{~m}^{-1}$ at $\left[\mathrm{H}_{2} \mathrm{O}_{2}\right] / \mathrm{COD}$ ratio values of 2.125, 1.063, and 0.531 , respectively, from an initial SUVA $=0.74$ (Figure $3 \mathrm{~b}$ ). After $3 \mathrm{~h}$ of treatment, SUVA value was constant, indicating that UV quenching substances were not being further removed.
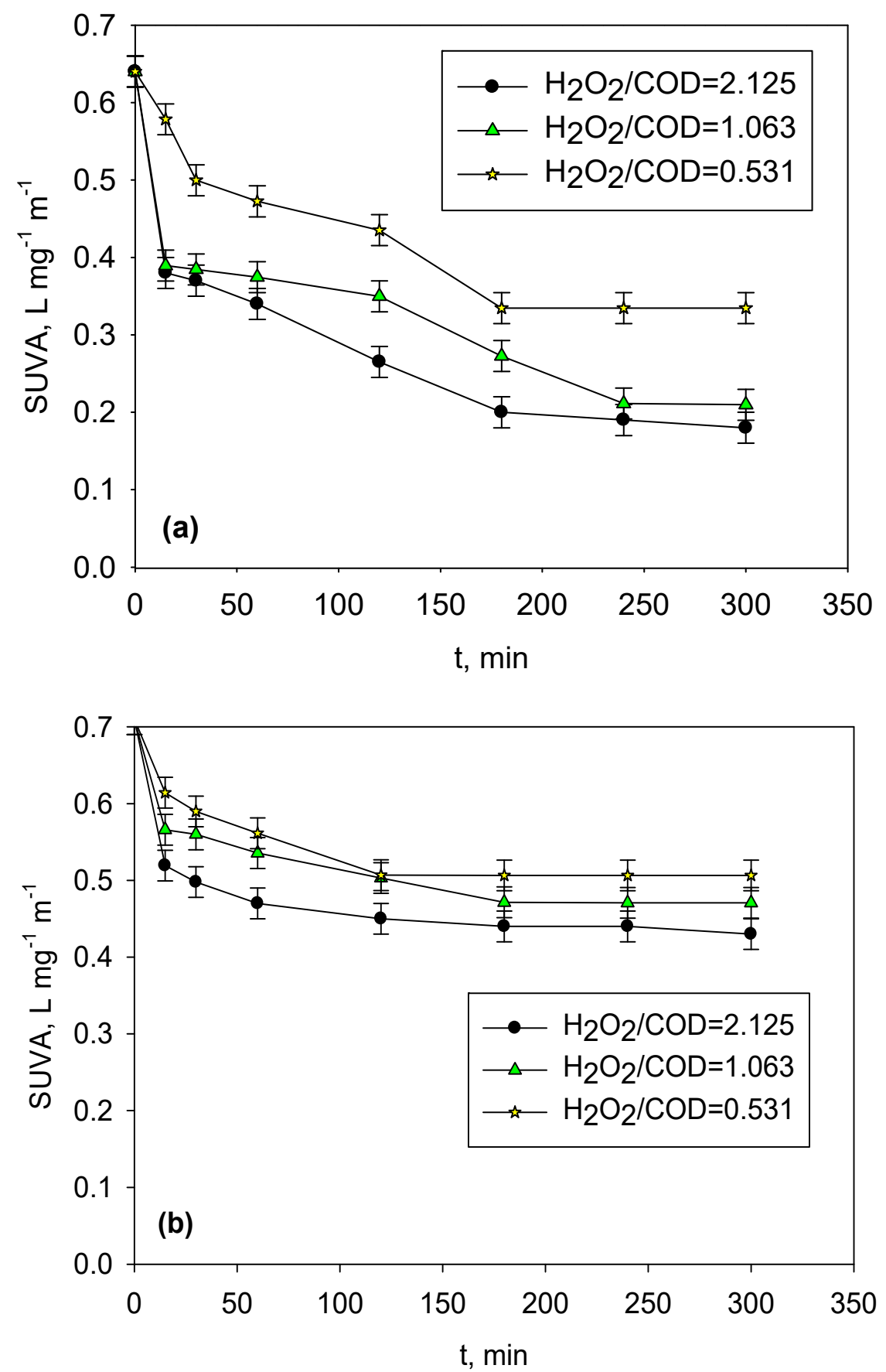

Figure 3. Specific ultraviolet absorption (SUVA) removal by the photo-Fenton treatment of pre-coagulated LLROC with: (a) $5 \mathrm{~g} \mathrm{~L}^{-1}$, and (b) $10 \mathrm{~g} \mathrm{~L}^{-1} \mathrm{FeCl}_{3} \cdot 6 \mathrm{H}_{2} \mathrm{O}$ (values are $\mathrm{m} \pm \mathrm{sd}$ ). 
Biodegradability enhancement during the photo-Fenton treatment mainly occurred at the beginning of the photo-oxidation process ( $20 \mathrm{~min}$; Figure $4 \mathrm{a}$ ), which would enable reducing oxidation treatment time and cost in a potential combination of this treatment sequence with a final biological step. Performing a photo-Fenton treatment with an $\left[\mathrm{H}_{2} \mathrm{O}_{2}\right] / \mathrm{COD}$ ratio of 1.063 will be enough to significantly $\left(p<0.001^{* * *}\right)$ enhance biodegradability up to $\mathrm{BOD}_{5} / \mathrm{COD} \approx 0.4$ if LLROC was previously coagulated with just $5 \mathrm{~g} \mathrm{~L}^{-1}$ of $\mathrm{FeCl}_{3} \cdot 6 \mathrm{H}_{2} \mathrm{O}$. The higher content of iron in the media, in the case of using $10 \mathrm{~g} \mathrm{~L}^{-1}$ of $\mathrm{FeCl}_{3} \cdot 6 \mathrm{H}_{2} \mathrm{O}$ in the coagulation step, did not significantly accelerated the oxidation process, and biodegradability was just improved up to $\mathrm{BOD}_{5} / \mathrm{COD} \approx 0.3$ (Figure $4 \mathrm{~b}$ ). This difference in the biodegradability increment can be explained by the more intensive oxidation that resulted for pre-coagulated leachate with $10 \mathrm{~g} \mathrm{~L}^{-1}$, and by the fact that the final products are less biodegradable than the final products when the pre-coagulation is carried out with $5 \mathrm{~g} \mathrm{~L}^{-1}$. In addition, the post-management of iron sludge will be cheaper coagulating with less amount of ferric chloride; and the added chloride to the media will be lower itself.
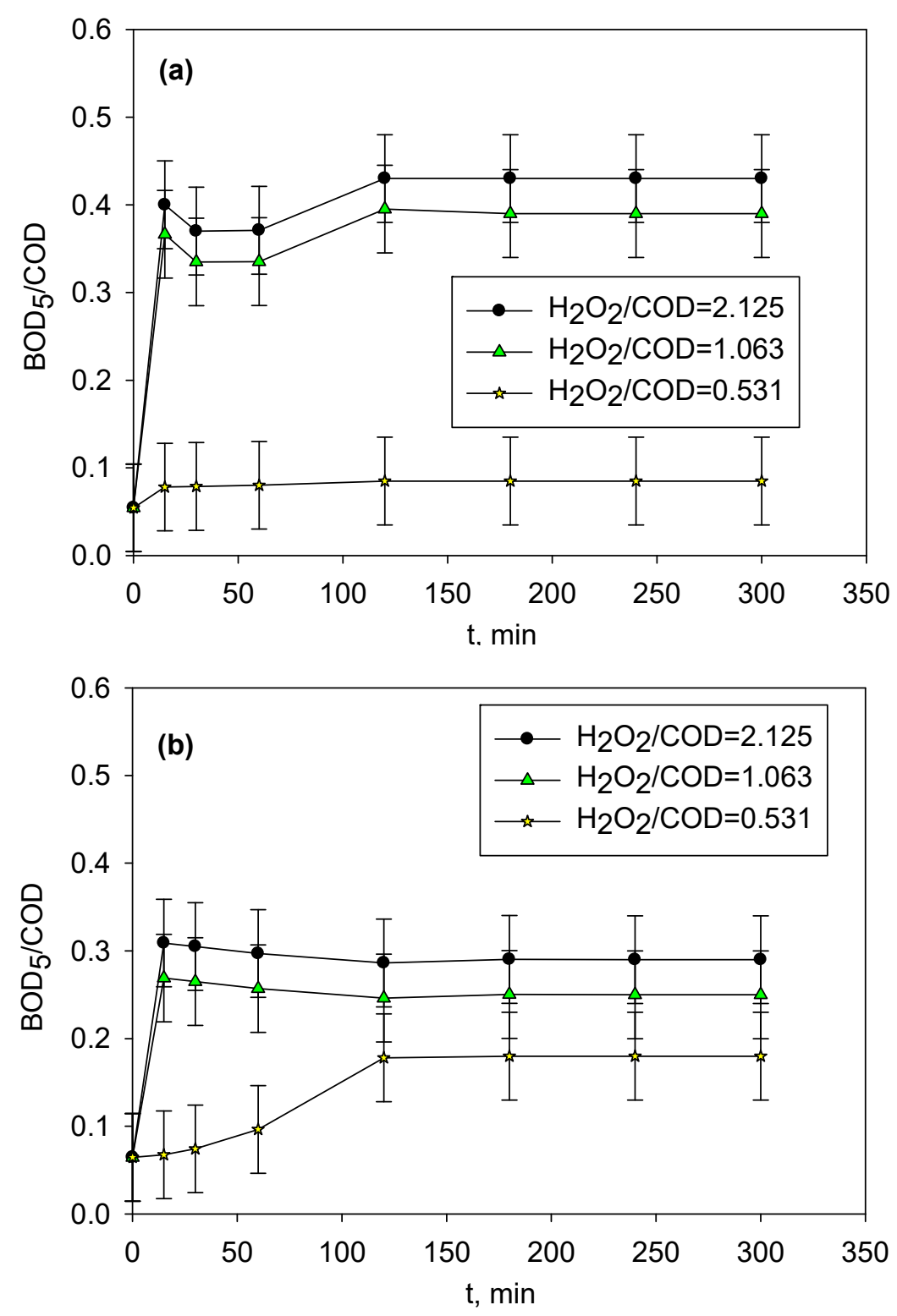

Figure 4. Biodegradability evolution along the photo-Fenton treatment of coagulated LLROC with: (a) $5 \mathrm{~g} \mathrm{~L}^{-1}$, and (b) $10 \mathrm{~g} \mathrm{~L}^{-1}$ of $\mathrm{FeCl}_{3} \cdot 6 \mathrm{H}_{2} \mathrm{O}$ (values are $\mathrm{m} \pm \mathrm{sd}$ ). 
Considering the source of radiation to perform the photo-Fenton treatment, the power consumption of immersion mercury lamps represents an important part of the cost of the treatment. For this reason, the photo-Fenton treatment using a $100 \mathrm{~W}$ immersion mercury lamp was compared with the use of a novel UVA-LED lamp designed to be more efficient, and, therefore, a significant reduction of the cost of this treatment is expected. As a result, COD removal and final biodegradability reached the same figures with both sources of radiation at the selected optimal conditions to perform the treatment.

The radiated energy in the UV region of the used mercury immersion lamp is reported by the manufacturer to be $15 \%$, whereas new mercury immersion lamps account for $40 \%$ radiation emitted in the UV region; so the power consumption of the mercury lamp technology was recalculated, as included in our previous work [41], and proper technological comparison could be made. In short, the application of LED technology resulted in a significant $\left(p<0.001^{* * *}\right)$ monetary saving of the $16.46 \%$ in terms of power consumption (as calculated from data on Table 3, which is further discussed in Section 2.4), besides lower costs of investment and disposal (environmental hazard of mercury) shall also be considered; as well as further optimization of the LED technology use might also contribute to even further reduce the final cost of treatment.

Table 3. LLROC treatment cost considering the same coagulation pre-treatment $(\mathrm{pH}=6$; coagulant dose $=5 \mathrm{~g} \mathrm{~L}^{-1}$ of ferric chloride) and lime precipitation post-treatment (calcium hydroxide dose = $30 \mathrm{~g} \mathrm{~L}^{-1}$ ) but different light sources (100 W mercury-vapor immersion lamp and UVA-LED lamp) for the photo-Fenton treatment.

\begin{tabular}{ccc}
\hline Treatment Costs & 100 W Mercury Lamp & UVA LED Lamp \\
\hline Power consumption, $€ \mathrm{~m} \mathrm{~m}^{-3}$ & 15.8 & 13.2 \\
Hydrogen peroxide, $€ \mathrm{~m} \mathrm{~m}^{-3}$ & 1.9 & 1.9 \\
\hline Photo-Fenton, $€ \mathrm{~m} \mathrm{~m}^{-3}$ & 17.7 & 15.1 \\
Pre-treatment, $€ \mathrm{~m}^{-3}$ & 4.2 & 4.2 \\
Post-treatment, $€ \mathrm{~m}^{-3}$ & 3.9 & 3.9 \\
\hline Total, $€ \mathrm{~m}^{-3}$ & 25.8 & 23.2 \\
Total, $€ \mathrm{~kg} \mathrm{COD}$ & 1.4 & 1.2 \\
\hline
\end{tabular}

Mean values are provided, $n=3$; standard deviation values were lower than $1 \%$.

\subsection{Lime Treatment}

Considering the results (Figure 5), $30 \mathrm{~g} \mathrm{~L}^{-1}$ of calcium hydroxide (lime, $\mathrm{Ca}(\mathrm{OH})_{2}$ ) was selected as the optimum dosage, for which the $\mathrm{pH}$ reached values of 12.38 and 12.46 for the oxidized LLROC that was previously coagulated with 5 and $10 \mathrm{~g} \mathrm{~L}^{-1}$ of $\mathrm{FeCl}_{3} \cdot 6 \mathrm{H}_{2} \mathrm{O}$, respectively. Higher doses of lime produce the dissolution of calcium, thus increasing calcium concentration in the medium, and, therefore, limiting the removal of sulfate.

Lime precipitation did not affect the biodegradability of the previously coagulated and oxidized LLROC in any tested case, although an extra 10-20\% removal of COD and TOC were produced at best. All other results for this treatment step (conductivity, color, SUVA, $\mathrm{TN}_{\mathrm{b}},\left[\mathrm{Cl}^{-}\right]$, and $\left[\mathrm{SO}_{4}{ }^{2-}\right]$ (Figure 5)) followed the same tendency for the two coagulant doses that were used in the pre-treatment of LLROC ( 5 and $10 \mathrm{~g} \mathrm{~L}^{-1}$ of $\mathrm{FeCl}_{3} \cdot 6 \mathrm{H}_{2} \mathrm{O}$ ) before its oxidation treatment. In both cases, SUVA was reduced down to $0.05 \mathrm{~L} \mathrm{mg}^{-1} \mathrm{~m}^{-1}$, and conductivity and color were removed by a $43 \%$ (final value $\approx 50 \mathrm{mS} \mathrm{cm}^{-1}$ ) and $99.9 \%$, respectively, from raw LLROC figures. In addition, an ammonium stripping process occurred as $\mathrm{pH}$ turned to basic values during lime treatment just by stirring the sample [54], achieving a $90 \%$ removal of the total nitrogen content from the wastewater in this last treatment step. 

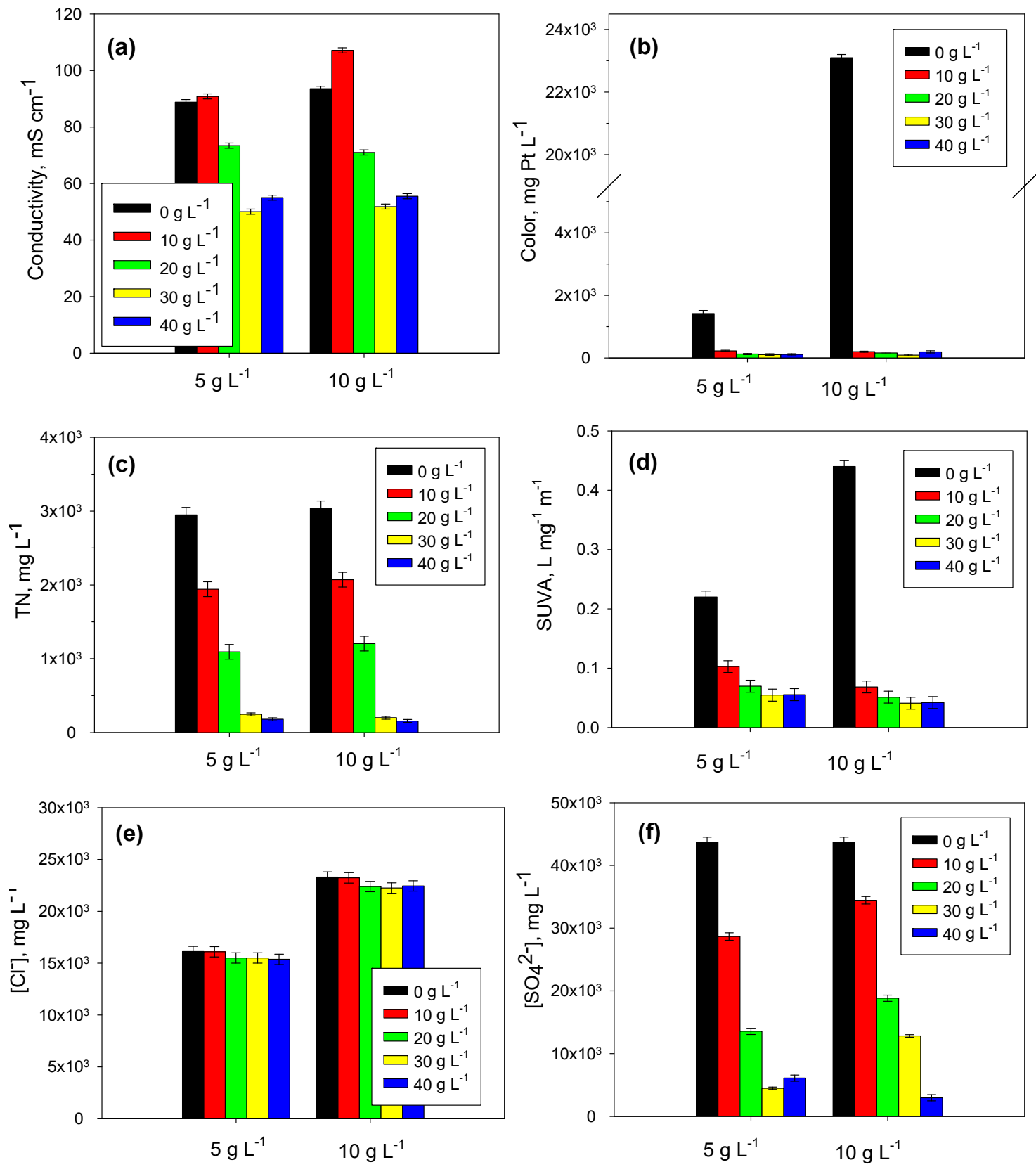

Figure 5. Lime precipitation results of previously oxidized coagulated LLROC $\left(\left[\mathrm{H}_{2} \mathrm{O}_{2}\right] / \mathrm{COD}=1.063\right.$; coagulant doses of 5 and $10 \mathrm{~g} \mathrm{~L}^{-1}$ of $\mathrm{FeCl}_{3} \cdot 6 \mathrm{H}_{2} \mathrm{O}$ ): (a) Conductivity; (b) color; (c) $\mathrm{TNb}$; (d) SUVA; (e) chloride; and (f) sulfate (values are $\mathrm{m} \pm \mathrm{sd}$ ).

The reduction of conductivity by lime precipitation is in accordance with the removal of sulfate and total nitrogen contents from the oxidized post-coagulated LLROC. The reduction of sulfate content (Figure $5 \mathrm{f}$ ) is explained by the induced precipitation of calcium sulfate. Initial sulfate levels were not so important $\left(\left[\mathrm{SO}_{4}{ }^{2-}\right]=2431 \mathrm{mg} \mathrm{L}^{-1}\right)$, but after the adjustment of $\mathrm{pH}$ with sulfuric acid, before the coagulation step, the reached value supposes an increment of sulfate concentration $\left(\left[\mathrm{SO}_{4}{ }^{2-}\right]=43,758 \mathrm{mg} \mathrm{L}^{-1}\right)$. Chloride is another ion present in the wastewater contributing to build up conductivity, but its content was not affected by this treatment step (Figure 5e). Metals content also contributes to produce conductivity and, in the case of iron, color as well. The increase of $\mathrm{pH}$ along this lime precipitation step produced the precipitation of iron in the form of $\mathrm{Fe}(\mathrm{OH})_{3}$. As a result, the final concentration of iron was below $0.5 \mathrm{mg} \mathrm{L}^{-1}$, whether its initial concentration was 168 or $800 \mathrm{mg} \mathrm{L}^{-1}$ after the photo-Fenton treatment ( 5 or $10 \mathrm{~g} \mathrm{~L}^{-1}$ of ferric chloride coagulation, respectively). Moreover, 
a considerable fraction of other metal, transition metal, or metalloid ions were precipitated, namely: $86 \%$ of $\mathrm{Al}, 77 \%$ of $\mathrm{Zn}, 84 \%$ of $\mathrm{Mn}, 99 \%$ of $\mathrm{Mg}$, and $98 \%$ of $\mathrm{Si}$.

\subsection{Economic Assessment}

Although a more economical result may be expected at industrial scale, the treatment cost of the herein assessed treatment at lab scale has been estimated in order to set reference values (Table 3). The following average values have been adopted as reference prices for each industrial grade reagent: Ferric chloride ( $\left.200 € \mathrm{ton}^{-1}, 40 \mathrm{wt} \%\right)$, alum ( $180 € \mathrm{ton}^{-1}$, pure), hydrogen peroxide ( $\left.350 € \mathrm{ton}^{-1}, 35 \mathrm{wt} \%\right)$, concentrated sulphuric acid $\left(130 €\right.$ ton $\left.^{-1}\right)$, and calcium hydroxide $\left(130 € \operatorname{ton}^{-1}\right)$. The cost of power was calculated using the average cost of electricity in Spain $\left(0.11 € \mathrm{kWh}^{-1}\right)$.

The application of UVA-LED technology produced an approximately $16 \%$ reduction in the cost of energy consumption in the photo-Fenton treatment step, which represents a $10 \%$ reduction in the total treatment cost. A cheaper implementation cost and the lower environmental hazard of its final disposal, as well as the potential to design an even more efficient LED lamp, may further foster the use of this technology for these environmental applications. In fact, Rodriguez-Chueca et al. (2016) [42] have similarly reported UVA-LED as a promising technology to more efficiently assist the photo-Fenton treatment. Moreover, the combination of coagulation $\left(\mathrm{pH}=5.0 ; 2 \mathrm{~g} \mathrm{~L}^{-1}\right.$ of $\mathrm{FeCl}_{3}$ ) with UVA-LED photo-Fenton oxidation was assessed to cost $1.56 € \mathrm{~kg} \mathrm{COD}^{-1}$ in a previous study [41], in which lime precipitation was not considered, denoting the importance of process optimization at lab scale and technology development in the short term.

\section{Material and Methods}

\subsection{Landfill Leachate ROC}

The LLROC sample was collected from "Las Dehesas-Valdemingómez" landfill (Madrid, Spain). The leachate of this landfill is treated by a three-stage RO system, achieving a $52 \%$ total recovery in the treatment of $200 \mathrm{~m}^{3}$ per day. In this process, LLROC, of which the main characteristics are shown in Table 1, is partially recirculated back to the landfill leachate tank, and the rest is collected by an external waste manager, implying a very high cost. Therefore, new alternatives are necessary.

\subsection{Chemicals}

Aluminum sulfate decaoctahydrate $\left(\mathrm{Al}_{2}\left(\mathrm{SO}_{4}\right)_{3} \cdot 18 \mathrm{H}_{2} \mathrm{O} ; 99.5 \%\right.$ min. purity) in a $50 \% w / w$ water solution, and ferric chloride $\left(\mathrm{FeCl}_{3} \cdot 6 \mathrm{H}_{2} \mathrm{O} ; 99 \%\right.$ min. purity) in a $69 \% w / w$ water solution were used as coagulants. Both chemicals were purchased from Sigma-Aldrich (Highland, CA, USA). An anionic flocculant of high molecular weight (A-120HMW) from Kemira (Helsinki, Finland) was used in a $0.025 \% w / w$ water solution. Lime $\left(\mathrm{Ca}(\mathrm{OH})_{2} ; 95 \%\right.$ min. purity) was purchased from Panreac Química S.L.U. (Castellar del Vallés, Spain), and used as powder. Sulfuric acid $\left(\mathrm{H}_{2} \mathrm{SO}_{4}, 96-98 \%\right.$ purity) from Sigma-Aldrich (Highland, CA, USA) was used for $\mathrm{pH}$ adjustment without further purification. Hydrogen peroxide (35\% w/w; Sigma-Aldrich, Highland, CA, USA) was used as oxidant in the photo-Fenton treatment of LLROC.

\subsection{Analytical Determinations and Data Processing}

All analyses were performed according to the Standard Methods for the Examination of Water and Wastewater [55]. Conductivity and $\mathrm{pH}$ were measured using a Sension ${ }^{\mathrm{TM}}+\mathrm{MM} 374 \mathrm{pH}-$ meter (Hach, CO, USA) equipped with $\mathrm{pH}$ and conductivity probes. COD, sulfate, and chloride contents were measured following the Nanocolor ${ }^{\circledR}$ test methods (Macherey-Nagel GmbH, Düren, Germany) and using an Aquamate UV-Vis spectrophotometer (Thermo Fisher Scientific, Waltham, MA, USA) to perform measurements. A Hanna LP 2000-11 turbidity-meter (Hanna Instruments, Laval, Canada) was used to determine turbidity. UV-254 absorbance was measured using a Varyan Cary 50 UV-visible spectrophotometer (Varian, Palo Alto, CA, USA) using 1-cm-pathway quartz-cuvettes (Hellma, 
Müllheim, Germany). Total organic carbon (TOC) and total nitrogen $\left(\mathrm{TN}_{\mathrm{b}}\right)$ were determined by the combustion-infrared method using a Multi N/C 3100 TOC/TN analyzer (Analytik Jena AG, Jena, Germany) with catalytic oxidation on cerium oxide at $850^{\circ} \mathrm{C} . \mathrm{H}_{2} \mathrm{O}_{2}$ concentration was determined by Pobiner's titanium sulfate spectrophotometric method [56]. Dissolved iron, aluminum, and calcium were measured by atomic absorption spectrometry $(3111 \mathrm{~B}, 3111 \mathrm{E})$ with a Varian SpectrAA 220 spectrophotometer (Varian, Palo Alto, CA, USA). 5-day biochemical oxygen demand ( $\mathrm{BOD}_{5}$ ) and total alkalinity were respectively determined following standard methods 5210B and 2320B [55]. Samples were filtered through $0.45 \mu \mathrm{m}$, and dilution was applied when necessary.

All analyses were carried out in triplicate; hence, all data provided in the text, figures (error bars), or tables are expressed in terms of the mean value $(\mathrm{m}) \pm$ the standard deviation $(\mathrm{sd})$ of measurements and results. ANOVA was performed to address the statistical significance ( $p$-value $<0.05 *, 0.01 * *$, or $0.001^{* * *}$ ) of resulting differences when necessary.

\subsection{Coagulation/Flocculation Pretreatment}

Both coagulants, $\mathrm{Al}_{2}\left(\mathrm{SO}_{4}\right)_{3} \cdot 18 \mathrm{H}_{2} \mathrm{O}$ and $\mathrm{FeCl}_{3} \cdot 6 \mathrm{H}_{2} \mathrm{O}$, were tested following a jar-test methodology at four different initial $\mathrm{pH}$ values $\left(8.2,7.0,6.0\right.$, and 5.0) and several dosages ranging from 0 to $30 \mathrm{~g} \mathrm{~L}^{-1}$, aiming to determine the optimum conditions for the removal of COD, color, and SUVA. Experiments were performed in a $500 \mathrm{~mL}$ beaker filled with $250 \mathrm{~mL}$ of sample in a flocculation tester. Fast mixing (150 rpm) was applied for $10 \mathrm{~min}$ after the coagulant was added. Then, the flocculant was added followed by $30 \mathrm{~min}$ of slow mixing $(50 \mathrm{rpm})$. Finally, the samples were left to settle for $60 \mathrm{~min}$ to achieve maximum clarification.

\subsection{Photo-Fenton Treatment}

Two different set-ups were used under the same experimental conditions to perform the photo-Fenton treatment after the coagulation/flocculation pretreatment of the LLROC. In the first setup, a high-pressure mercury vapor immersion lamp of $100 \mathrm{~W}$ (Model 7825-30 from ACE Glass, Vineland, NJ, USA) that was covered by a quartz glass cooling jacket, and vertically positioned in the reactor, was used as the source of radiation, as it has previously been described [41]. A total photon flux of $6.6 \times 10^{18}$ photon $\mathrm{s}^{-1} \mathrm{~m}^{-2}$ was measured to be emitted inside the reactor using a radiometer (UV-Elektronik, UV-VIS Radiometer RM-21, Ettlingen, Germany) [57]. $1.75 \mathrm{~L}$ of coagulated leachate was mechanically stirred in the reactor. The appropriate amount of $\mathrm{H}_{2} \mathrm{O}_{2}(35 \% w / v)$ corresponding to initial $\left[\mathrm{H}_{2} \mathrm{O}_{2}\right] /[\mathrm{COD}]$ ratios of 2.125 (stoichiometric theoretical optimum [51]), 1.063 and 0.531 , was then added.

In the second photo-Fenton treatment setup, the source of radiation consisted of an 8W UVA LED lamp made up of 10,365 nm LED emitters (CUN6GB1A, Seoul Viosys, Asan, Korea) uniformly disposed in series over the $9 \mathrm{~cm}$ diameter reactor, which was filled with $100 \mathrm{~mL}$ of the post-coagulated LLROC that were magnetically stirred. The lamp was located at $4.5 \mathrm{~cm}$ from LLROC surface. $250 \mathrm{~mA}$ of current intensity were applied to generate a total photon flux in the solution contained in the reactor of $1.0 \times 10^{21}$ photon $\mathrm{s}^{-1} \mathrm{~m}^{-2}$, as measured by potassium ferrioxalate actinometry [58,59]. Trials were carried out in triplicate, at room temperature, and without adjusting the initial $\mathrm{pH}$ value.

\subsection{Lime Precipitation Step}

Calcium hydroxide powder was added to the previously oxidized coagulated LLROC at dosages ranging from 0 to $40 \mathrm{~g} \mathrm{~L}^{-1}$. The samples were mechanically stirred at $150 \mathrm{rpm}$ for $16 \mathrm{~h}$, and then were left to settle for $60 \mathrm{~min}$. This treatment was carried out using the same equipment than in the coagulation/flocculation treatment.

\section{Conclusions}

The pre-treatment of coagulation/flocculation with ferric chloride achieved better COD removal results than with alum ( $76 \%$ vs. $60 \%$ ), and the remaining dissolved iron in the LLROC after coagulation 
was efficiently used for its post-photo-Fenton treatment step, avoiding the need to add more iron to the solution to catalyze the process.

Photo-Fenton treatment after optimum coagulation with ferric chloride was efficient in enhancing the biodegradability of LLROC to $\mathrm{BOD}_{5} / \mathrm{COD}$ ratios of $\approx 0.3-0.4$, as well as in the removal of COD $(45 \%)$, TOC (44\%), and SUVA ( $46 \%)$.

The most important difference between optimal coagulant doses, with regard to a posterior photo-Fenton process, was the dissolved iron content that remained in the medium $\left(168\right.$ and $800 \mathrm{mg} \mathrm{L}^{-1}$ of $\mathrm{Fe}$ for 5 and $10 \mathrm{~g} \mathrm{~L}^{-1}$ of $\mathrm{FeCl}_{3} \cdot 6 \mathrm{H}_{2} \mathrm{O}$ coagulation, respectively) affecting the kinetics of the reaction; so that the time of irradiation was reduced from $300 \mathrm{~min}$ to $180 \mathrm{~min}$, respectively.

The cost of managing higher amounts of residual iron in the medium after treatment, the better biodegradability improvement results $\left(\mathrm{BOD}_{5} / \mathrm{COD}=0.4\right)$, and the lower chloride addition to the media, indicate that, in these terms, coagulation with $5 \mathrm{~g} \mathrm{~L}^{-1}$ of $\mathrm{FeCl}_{3} \cdot 6 \mathrm{H}_{2} \mathrm{O}$ may be preferred for the coagulation step.

The use of UVA-LED technology as the source of irradiation in the photo-Fenton treatment may reduce the cost of power consumption by up to $16 \%$ compared with using $100 \mathrm{~W}$ UV mercury immersion lamps, and this is significant because longer reaction time (thus longer lamp use) is required when lower iron content remains in the medium after coagulation. The substitution of a $100 \mathrm{~W}$ UV mercury immersion lamp by UVA-LED technology addressed an overall 10\% cheaper treatment, which may be further enhanced with further optimization of this new technology.

A final step of lime precipitation $\left(30 \mathrm{~g} \mathrm{~L}^{-1}, 24 \mathrm{~h}\right)$ lowered conductivity by $50 \%$, sulfate and nitrogen content by $90 \%$, and iron content by $99.9 \%$, in the oxidized-coagulated-LLROC.

The assessed best combination of treatments (ferric chloride coagulation + UVA-LED photo-Fenton + lime addition) for LLROC achieved an overall removals of $90 \%$ COD, $43 \%$ conductivity, $86 \%$ aluminum, $77 \%$ zinc, $84 \%$ manganese, $99 \%$ magnesium, and $98 \%$ silicon; as well as an enhancement of biodegradability, increasing the $\mathrm{BOD}_{5} / \mathrm{COD}$ ratio from 0.06 to 0.4 .

Author Contributions: Conceptualization, J.T., D.H., R.M., A.G., V.A., C.N. and Á.B.; methodology, J.T., D.H., R.M., A.G., V.A., C.N. and Á.B.; formal analysis, J.T., D.H. and A.G.; investigation, J.T., D.H., R.M., A.G. and V.A.; data curation, J.T., and A.G.; writingoriginal dra-ft preparation, J.T., D.H., R.M., A.G., V.A., C.N. and Á.B.; writing-review and editing, J.T., D.H., R.M., A.G., V.A., C.N. and Á.B.; supervision, D.H., R.M., A.G., C.N. and Á.B; funding acquisition, Á.B. All authors have read and agreed to the published version of the manuscript.

Funding: This piece of research has been funded by the Spanish Ministry of Economy, Industry and Competitiveness granting project CTM2016-77948-R, and by the Community of Madrid by funding project RETOPROSOST-2 (S2018/EMT-4459).

Acknowledgments: The authors acknowledge to Las Dehesas-Valdemingómez landfill (Madrid, Spain) for kindly supplying the ROCLL used in this study.

Conflicts of Interest: The authors declare no conflict of interest.

\section{References}

1. Koc-Jurczyk, J.; Jurczyk, L. Biological treatment of landfill leachate at elevated temperature in the presence of polyurethane foam of various porosity. Clean Soil Air Water 2017, 45, 8. [CrossRef]

2. Ye, Z.L.; Hong, Y.; Pan, S.; Huang, Z.; Chen, S.; Wang, W. Full-scale treatment of landfill leachate by using the mechanical vapor recompression combined with coagulation pretreatment. Waste Manag. 2017, 66, 88-96. [CrossRef] [PubMed]

3. Teh, C.Y.; Budiman, P.M.; Shak, K.P.Y.; Wu, T.Y. Recent advancement of oagulation-flocculation and its application in wastewater treatment. Ind. Eng. Chem. Res. 2016, 55, 4363-4389. [CrossRef]

4. Torretta, V.; Ferronato, N.; Katsoyiannis, I.A.; Tolkou, A.K.; Airoldi, M. Novel and conventional technologies for landfill leachates treatment: A Review. Sustainability 2017, 9, 9. [CrossRef]

5. Oller, I.; Malato, S.; Sánchez-Pérez, J.A. Combination of advanced oxidation processes and biological treatments for wastewater decontamination-A review. Sci. Total Environ. 2011, 409, 4141-4166. [CrossRef] 
6. Trebouet, D.; Schlumpf, J.P.; Jaouen, P.; Quemeneur, F. Stabilized landfill leachate treatment by combined physicochemical-nanofiltration processes. Water Res. 2001, 35, 2935-2942. [CrossRef]

7. Bohdziewicz, J.; Bodzek, M.; Górska, J. Application of pressure-driven membrane techniques to biological treatment of landfill leachate. Process. Biochem. 2001, 36, 641-646. [CrossRef]

8. Weber, B.; Holz, F. Landfill leachate treatment by reverse osmosis. In Effective Industrial Membrane Processes: Benefits and Opportunities; Turner, M.K., Ed.; Springer: Dordrecht, The Netherlands, 1991; pp. 143-154.

9. Van der Bruggen, B.; Lejon, L.; Vandecasteele, C. Reuse, treatment, and discharge of the concentrate of pressure-driven membrane processes. Environ. Sci. Technol. 2003, 37, 3733-3738. [CrossRef]

10. Zhao, R.; Jung, C.; Trzopek, A.; Torrens, K.; Deng, Y. Characterization of ultraviolet-quenching dissolved organic matter (DOM) in mature and young leachates before and after biological pre-treatment. Environ. Sci. Water Res. Technol. 2018, 4, 731-738. [CrossRef]

11. Iskander, S.M.; Novak, J.T.; Brazilb, B.; He, Z. Percarbonate oxidation of landfill leachates towards removal of ultraviolet quenchers. Environ. Sci. Water Res. Technol. 2017, 3, 1162-1170. [CrossRef]

12. Zhou, B.; Yu, Z.; Wei, Q.; Long, H.Y.; Xie, Y.; Wang, Y. Electrochemical oxidation of biological pretreated and membrane separated landfill leachate concentrates on boron doped diamond. Appl. Surf. Sci. 2016, 377, 406-415. [CrossRef]

13. Morello, L.; Cossu, R.; Raga, R.; Pivato, A.; Lavagnolo, M.C. Recirculation of reverse osmosis concentrate in lab-scale anaerobic and aerobic landfill simulation reactors. Waste Manag. 2016, 56, 262-270. [CrossRef] [PubMed]

14. Calabrò, P.S.; Gentili, E.; Meoni, C.; Orsi, S.; Komilis, D. Effect of the recirculation of a reverse osmosis concentrate on leachate generation: A case study in an Italian landfill. Waste Manag. 2018, 76, 643-651. [CrossRef] [PubMed]

15. Labiadh, L.; Fernandes, A.; Ciriaco, L.; Pacheco, M.J.; Gadri, A.; Ammar, S. Electrochemical treatment of concentrate from reverse osmosis of sanitary landfill leachate. J. Environ. Manag. 2016, 181, 515-521. [CrossRef] [PubMed]

16. Talalaj, I.A.; Biedka, P. Impact of concentrated leachate recirculation on effectiveness of leachate treatment by reverse osmosis. Ecol. Eng. 2015, 85, 185-192. [CrossRef]

17. Qi, X.X.; Zhang, C.J.; Zhang, Y. Treatment of landfill leachate RO concentrate by VMD. In Proceedings of the International Conference on Circuits and Systems, Madrid, Spain, 20-21 July 2015; Volume 9, pp. $13-17$.

18. Yang, B.Q.; Yang, J.M.; Yang, H.; Liu, Y.M.; Li, X.K.; Wang, Q.Z.; Pan, X.J. Co-bioevaporation treatment of concentrated landfill leachate with addition of food waste. Biochem. Eng. J. 2018, 130, 76-82. [CrossRef]

19. Bagastyo, A.Y.; Radjenovic, J.; Mu, Y.; Rozendal, R.A.; Batstone, D.J.; Rabaey, K. Electrochemical oxidation of reverse osmosis concentrate on mixed metal oxide (MMO) titanium coated electrodes. Water Res. 2011, 45, 4951-4959. [CrossRef]

20. Pérez, G.; Fernández-Alba, A.R.; Urtiaga, A.M.; Ortiz, I. Electro-oxidation of reverse osmosis concentrates generated in tertiary water treatment. Water Res. 2010, 44, 2763-2772. [CrossRef]

21. He, Y.; Zhang, H.; Li, J.J.; Zhang, Y.; Lai, B.; Pan, Z. Treatment of landfill leachate reverse osmosis concentrate by catalytic ozonation with $\gamma-\mathrm{Al}_{2} \mathrm{O}_{3}$. Environ. Eng. Sci. 2018, 35, 501-511. [CrossRef]

22. Mojiri, A.; Ziyang, L.; Hui, W.; Gholami, A. Concentrated landfill leachate treatment by electro-ozonation. In Advanced Oxidation Processes (AOPS) in Water and Wastewater Treatment; Aziz, H.A., Abu Amr, S.S., Eds.; IGI Global: Hershey, PA, USA, 2019; pp. 150-170.

23. Cui, Y.H.; Xue, W.J.; Yang, S.Q.; Tu, J.L.; Guo, X.L.; Liu, Z.Q. Electrochemical/peroxydisulfate/Fe ${ }^{3+}$ treatment $^{2}$ of landfill leachate nanofiltration concentrate after ultrafiltration. Chem. Eng. J. 2018, 353, 208-217. [CrossRef]

24. Liang, S.X.; Jia, Z.; Zhang, W.C.; Lia, X.F.; Wang, W.M.; Line, H.C.; Zhang, L.C. Ultrafast activation efficiency of three peroxides by $\mathrm{Fe}_{78} \mathrm{Si}_{9} \mathrm{~B}_{13}$ metallic glass under photo-enhanced catalytic oxidation: A comparative study. Appl. Catal. B 2018, 221, 108-118. [CrossRef]

25. Hermosilla, D.; Cortijo, M.; Huang, C.P. Optimizing the treatment of landfill leachate by conventional Fenton and photo-Fenton processes. Sci. Total Environ. 2009, 407, 3473-3481. [CrossRef] [PubMed]

26. Liang, S.X.; Jia, Z.; Liu, Y.J.; Zhang, W.; Wang, W.; Lu, J.; Zhang, L.C. Compelling rejuvenated catalytic performance in metallic glasses. Adv. Mater. 2018, 30, 1802764. [CrossRef] [PubMed]

27. Wang, Q.; Chen, M.; Lin, P.; Cui, Z.; Chu, C.; Shen, B. Investigation of FePC amorphous alloys with self-renewing behaviour for highly efficient decolorization of methylene blue. J. Mater. Chem. A 2018, 6, 10686. [CrossRef] 
28. Martín, M.B.; López, J.C.; Oller, I.; Malato, S.; Pérez, J.S. A comparative study of different tests for biodegradability enhancement determination during AOP treatment of recalcitrant toxic aqueous solutions. Ecotoxicol. Environ. Saf. 2010, 73, 1189-1195. [CrossRef] [PubMed]

29. Paździor, K.; Bilińska, L.; Ledakowicz, S. A review of the existing and emerging technologies in the combination of AOPs and biological processes in industrial textile wastewater treatment. Chem. Eng. J. 2019, 376, 120597. [CrossRef]

30. Umar, M.; Roddick, F.; Fan, L.H. Recent advancements in the treatment of municipal wastewater reverse osmosis concentrate-An overview. Crit. Rev. Environ. Sci. Technol. 2015, 45, 193-248. [CrossRef]

31. Dialynas, E.; Mantzavinos, D.; Diamadopoulos, E. Advanced treatment of the reverse osmosis concentrate produced during reclamation of municipal wastewater. Water Res. 2008, 42, 4603-4608. [CrossRef]

32. Liu, K.; Roddick, F.A.; Fan, L. Impact of salinity and $\mathrm{pH}$ on the $\mathrm{UVC} / \mathrm{H}_{2} \mathrm{O}_{2}$ treatment of reverse osmosis concentrate produced from municipal wastewater reclamation. Water Res. 2012, 46, 3229-3239. [CrossRef]

33. Zheng, H.; Pan, Y.; Xiang, X. Oxidation of acidic dye Eosin $Y$ by the solar photo-Fenton processes. J. Hazard. Mater. 2007, 141, 457-464. [CrossRef]

34. Aziz, H.A.; Alias, S.; Adlan, M.N.; Faridah; Asaari, A.H.; Zahari, M.S. Colour removal from landfill leachate by coagulation and flocculation processes. Bioresour. Technol. 2007, 98, 218-220. [CrossRef] [PubMed]

35. Zhou, T.; Lim, T.T.; Chin, S.S.; Fane, A.G. Treatment of organics in reverse osmosis concentrate from a municipal wastewater reclamation plant: Feasibility test of advanced oxidation processes with/without pretreatment. Chem. Eng. J. 2011, 166, 932-939. [CrossRef]

36. Kavitha, V.; Palanivelu, K. The role of ferrous ion in Fenton and photo-Fenton processes for the degradation of phenol. Chemosphere 2004, 55, 1235-1243. [CrossRef] [PubMed]

37. Safarzadeh-Amiri, A.; Bolton, J.R.; Cater, S.R. Ferrioxalate-mediated photodegradation of organic pollutants in contaminated water. Water Res. 1997, 31, 787-798. [CrossRef]

38. Hermosilla, D.; Cortijo, M.; Huang, C.P. The role of iron on the degradation and mineralization of organic compounds using conventional Fenton and photo-Fenton processes. Chem. Eng. J. 2009, 155, 637-646. [CrossRef]

39. Amor, C.; de Torres-Socias, E.; Peres, J.A.; Maldonado, M.I.; Oller, I.; Malato, S.; Lucas, M.S. Mature landfill leachate treatment by coagulation/flocculation combined with Fenton and solar photo-Fenton processes. J. Hazard. Mater. 2015, 286, 261-268. [CrossRef] [PubMed]

40. Renou, S.; Givaudan, J.G.; Poulain, S.; Dirassouyan, F.; Moulin, P. Treatment process adapted to stabilized leachates: Lime precipitation-prefiltration-reverse osmosis. J. Membr. Sci. 2008, 313, 9-22. [CrossRef]

41. Tejera, J.; Miranda, R.; Hermosilla, D.; Urra, I.; Negro, C.; Blanco, A. Treatment of a mature landfill leachate: Comparison between homogeneous and heterogeneous photo-Fenton with different pretreatments. Water 2019, 11, 1849. [CrossRef]

42. Rodríguez-Chueca, J.; Amor, C.; Fernandes, J.R.; Tavares, P.B.; Lucas, M.S.; Peres, J.A. Treatment of crystallized-fruit wastewater by UV-A LED photo-Fenton and coagulation-flocculation. Chemosphere 2016, 145, 351-359. [CrossRef]

43. Gomes, A.I.; Silva, T.F.C.V.; Duarte, M.A.; Boaventura, R.A.R.; Vilar, V.J.P. Cost-effective solar collector to promote photo-Fenton reactions: A case study on the treatment of urban mature leachate. J. Clean. Prod. 2018, 199, 369-382. [CrossRef]

44. Silva, T.F.; Fonseca, A.; Saraiva, I.; Boaventura, R.A.; Vilar, V.J. Scale-up and cost analysis of a photo-Fenton system for sanitary landfill leachate treatment. Chem. Eng. J. 2016, 283, 76-88. [CrossRef]

45. Chow, C.W.K.; van Leeuwen, J.A.; Fabris, R.; Drikas, M. Optimised coagulation using aluminium sulfate for the removal of dissolved organic carbon. Desalination 2009, 245, 120-134. [CrossRef]

46. Renou, S.; Givaudan, J.G.; Poulain, S.; Dirassouyan, F.; Moulin, P. Landfill leachate treatment: Review and opportunity. J. Hazard. Mater. 2008, 150, 468-493. [CrossRef] [PubMed]

47. Bacardit, J.; Stötzner, J.; Chamarro, E.; Esplugas, S. Effect of salinity on the photo-Fenton process. Ind. Eng. Chem. Res. 2007, 46, 7615-7619. [CrossRef]

48. Qin, J.J.; Oo, M.H.; Kekre, K.A.; Knops, F.; Miller, P. Impact of coagulation pH on enhanced removal of natural organic matter in treatment of reservoir water. Sep. Purif. Technol. 2006, 49, 295-298. [CrossRef]

49. Chen, W.; Gu, Z.; Wen, P.; Li, Q. Degradation of refractory organic contaminants in membrane concentrates from landfill leachate by a combined coagulation-ozonation process. Chemosphere 2019, 217, 411-422. [CrossRef] [PubMed] 
50. Biglarijoo, N.; Mirbagheri, S.A.; Ehteshami, M.; Ghaznavi, S.M. Optimization of Fenton process using response surface methodology and analytic hierarchy process for landfill leachate treatment. Process. Saf. Environ. Prot. 2016, 104, 150-160. [CrossRef]

51. Hermosilla, D.; Merayo, N.; Ordóñez, R.; Blanco, A. Optimization of conventional Fenton and ultraviolet-assisted oxidation processes for the treatment of reverse osmosis retentate from a paper mill. Waste Manag. 2012, 32, 1236-1243. [CrossRef]

52. Liu, R.; Chiu, H.M.; Shiau, C.S.; Yeh, R.Y.L.; Hung, Y.T. Degradation and sludge production of textile dyes by Fenton and photo-Fenton processes. Dyes Pigm. 2007, 73, 1-6. [CrossRef]

53. Iskander, S.M.; Zhao, R.; Pathak, A.; Gupta, A.; Pruden, A.; Novak, J.T.; He, Z. A review of landfill leachate induced ultraviolet quenching substances: Sources, characteristics, and treatment. Water Res. 2018, 145, 297-311. [CrossRef]

54. De, S.; Hazra, T.; Dutta, A. Sustainable treatment of municipal landfill leachate by combined association of air stripping, Fenton oxidation, and enhanced coagulation. Environ. Monit. Assess. 2019, 191, 49. [CrossRef] [PubMed]

55. APHA; AWWA; WPCF. Standard Methods for the Examination of Water and Wastewater; APHA: Washington, DC, USA, 2005.

56. Pobiner, H. Determination of hydroperoxides in hydrocarbon by conversion to hydrogen peroxide and measurement by titanium complexing. Anal. Chem. 1961, 33, 1423-1426. [CrossRef]

57. Liang, X.; Zhu, X.; Butler, E.C. Comparison of four advanced oxidation processes for the removal of naphthenic acids from model oil sands process water. J. Hazard. Mater. 2011, 190, 168-176. [CrossRef] [PubMed]

58. Hatchard, C.; Parker, C.A. A new sensitive chemical actinometer. II. Potassium ferrioxalate as a standard chemical actinometer. Proc. R. Soc. A. 1956, 235, 518-536.

59. Montalti, M.; Credi, A.; Prodi, L.; Gandolfi, M.T. Handbook of Photochemistry, 1st ed.; CRC Press: Boca Raton, FL, USA, 2006; p. 650.

Publisher's Note: MDPI stays neutral with regard to jurisdictional claims in published maps and institutional affiliations.

(C) 2020 by the authors. Licensee MDPI, Basel, Switzerland. This article is an open access article distributed under the terms and conditions of the Creative Commons Attribution (CC BY) license (http://creativecommons.org/licenses/by/4.0/). 